\title{
PERTALIAN TRADISI \\ KERIS TANGGUH NGÉNTHA-ÉNTA YOGYAKARTA: Titik Awal dan Kebangkitan Historis
}

\author{
Supriaswoto dan Timbul Haryono *)
}

\begin{abstract}
Kerris is stabbing weapon for the archipelago wich have a term of religious, values, magical, aesthetic, and mysterious, but also have a politic value, economy, sociology, and art that not timeless. It prove that kerris existence still exists and continuous to exists. The one that get tracked is Tangguh Ngentha-entha Kerris of Yagyakarta. Who masters that become the supportersand how Tangguh Ngentha-entha Kerris rise back and found their identifycan be listened to in the following text.
\end{abstract}

Keyword: Kerris, Tangguh Ngentha-entha, empu, Entha Wayang.

\section{Pendahuluan}

Keberadaan tradisi keris Tangguh Ngéntha-éntha Yogyakarta saat ini, telah memberi arti tersendiri bagi perkembangan historis keris Jawa, di Yogyakarta khususnya maupun Indonesia pada umumnya. Menurut pengamatan Isaac Groneman, seorang pemerhati perkembangan budaya keris Jawa, sebelum tahun 1910, seni tempa logam keris telah mundur demikian jauh, menjadi ancaman sejak permintaan senjata-senjata semakin berkurang (1910:91). Aktivitas keberadaan pusat-pusat besalèn keris berkurang, karena dukungan penyangganya surut. Besalèn adalah rumah berukuran sekitar $4 \times 6$ meter berfungsi sebagai tempat kerja empu keris yang dilengkapi alat-alat, seperti perapian, besi paron, pukul besi, blower atau ububan, dan sebagainya. Kondisi itu pun tidak luput menerpa pusat keris di
Desa Ngéntha-éntha, Sleman, Yogyakarta. Ancaman kemunduran justru tidak semakin surut, bahkan tahun 1960-an, satu-satunya besalèn keris di Desa Ngéntha-éntha milik keluarga Empu Supoinangun, aktivitasnya lumpuh. Selain permintaan berkurang, Empu Supoinangun sudah tua, dan meninggal pada tahun 1963. Kelumpuhan tersebut tidak kunjung bangkit, karena kondisi sosial, politik, dan ekonomi menjelang tahun 1965 yang semakin tidak mendukung. Akibatnya aktivitas besalèn keris di Desa Ngéntha-éntha tersebut menjadi lumpuh total.

Kelumpuhan berlangsung cukup lama, kurang lebih satu dasawarsa, namun tidak lantas memutus harapan untuk bangkit. Jeno Harumbrojo, anak bungsu Empu Supoinangun tahun 1970 sampai menjelang tahun 1973, terinspirasi untuk menjadi empu keris menyambung pertalian profesi mendiang orang tua maupun nenek moyangnya.

\footnotetext{
* Supriaswoto (priart.jogja@gmail.com), Staf Pengajar Program Studi Kriya Seni, Jurusan Kriya, Fakultas Seni Rupa, Institut Seni Indonesia Yogyakarta

* Timbul Haryono, Staf Pengajar Fakultas Ilmu Budaya Universitas Gadjah Mada Yogyakarta
} 
Tumbuh bibit kebulatan tekad dari Harumbrojo bersaudara untuk mengakhiri masa transisi kelumpuhan profesi keahlian membuat keris semakin kuat. Oleh karena tekad Harumbojo bersaudara juga disambut oleh lain pihak, tumbuh kesadaran para pemerhati keris untuk bersinergi membangkitkan keris dari kelumpuhan. Berkat sinergi dan kesadaran bersama akan pentingnya tradisi pembuatan keris, kelumpuhan aktivitas besalèn di Desa Ngéntha-éntha dapat tertolong, hidup kembali, bahkan kemudian menjadi kiblat bagi pengembangan keris di Indonesia.

Kebangkitan atau keruntuhan aktivitas budaya dapat terjadi karena, menurut Fritjof Capra, adanya suatu transisi dari kondisi statis ke aktivitas dinamis (1997:12). Berkaitan dengan aktivitas besalèn keris Tangguh Ngéntha-éntha Yogyakarta, tahun 1973 sampai menjelang tahun 1975 adalah masa untuk memperjuangkan aktivitas dinamis. Putra-putra Empu Supoinangun menggali kembali pengetahuan dan teknik keris untuk menyatukan sejarah yang terpotong pada masa silam sebelum itu. Persoalan yang harus diatasi dalam perjuangan membuat keris baru saat itu ternyata tidak sederhana. Menurut Capra, sejarah terlahir dari konflik, perjuangan, revolusi, penderitaan, dan pengorbanan manusia bagi perubahan (1997:23). Rintangan yang berupa keraguan sering muncul, tetapi karena ada dorongan dari luar, maka penggalian tetap berjalan dan akhirnya memenuhi harapan bersama.

Tidak sia-sia, perjuangan para pewaris Empu Supoinangun telah menepis pandangan yang dikhawatirkan banyak pihak, bahwa pembuatan keris sudah mati. Meskipun sesungguhnya menurut Umar Kayam, masyarakat sedang dirobek oleh unsur-unsur pembaruan. Seni bukan lagi menjadi kesatuan masyarakat, tetapi menjadi seni yang dijajakan (1981: 68). Nilai seni lama amat sukar diterima oleh masyarakatnya sendiri, karena terfokus pada produk hasil teknologi modern. Hal ini juga tidak menyurutkan perjuangan Harumbrojo bersaudara yang mengarah kepada masa depan keris sebagai jati diri bangsa. Mereka mencoba menempatkan keris sebagai karya seni tradisi yang kaya akan makna. Kekuatan keris bukan lagi seberapa besar kesaktiannya dari aspek mistik, tetapi visi berpikir tentang seni budaya dan persenjataan pada zamannya. Jean Durignand mengatakan bahwa karya seni tidak terbatas menggambarkan lebih banyak eksistensi materialnya, tetapi karya seni menciptakan kembali tatanan yang menyatukan fragmen-fragmen manusia yang terpisah dibelakang (2009:3). Dalam hal ini Desa Ngéntha-éntha masih menyimpan fragmen atau kisah keturunan empu keris, Achmad Fedyani Saefuddin menyebutkan bahwa citra seni tradisi sering dikaitkan dengan sentralitas, faktor keturunan ikut menekankan pentingnya kesinambungan (2006:39).

Regenerasi memang terputus, tetapi Harumbrojo bersaudara pernah menjadi bagian dari proses keris ketika kecil bersama empu keris, orang tuanya sendiri. Sesulit apapun proses keris, tetap mampu dikuasai, karena mereka membawa bakat keturunan. Mereka tinggal mengambil kerangka fantasi masa lalu dan memanfaatkan ruang yang kosong dari produk tradisi di dalam kerangka sosial baru. Terbukti sejarah tradisi unik keris Tangguh Ngéntha-éntha Yogyakarta tersambung kembali, meskipun mekanisme perjuangan menguasai pengetahuan dan teknik keris secara sempurna menurut Harumbojo, dibutuhkan waktu sekitar enam tahun lamanya (Kedaulatan Rakyat, 1997).

Kelahiran keris Tangguh Ngénthaéntha Yogyakarta baru, bersifat meniru 
seluruh apa yang pernah dibuat pendahulunya, jadi bukan mencari nilai kebaruan yang kreatif dan inovatif. Pencarian ini menyangkut sifat kekhasan kolektivitasnya dalam tradisi keris. Tentu sederetan empuempu telah menjadi bagian dari proses tradisi dan historis Tangguh Ngéntha-éntha Yogyakarta tersebut. Menurut Kayam, tradisi memang tidak pernah tertempa dalam waktu yang pendek, ia membutuhkan waktu yang lama untuk membiarkan kebiasaan berjalan matang menjadi tradisi (Kayam, 1981: 97). Lantas siapa, kapan, dan bagaimana di balik proses tradisi keris tangguh Ngéntha-éntha Yogyakarta itu terjadi. Baik ketika dulu di awal kelahiran sampai perjalanan hidupnya kini, perlu didapatkan kronologi historisnya.

\section{Awal Mula Keris Tangguh Ngéntha-Entha Yogyakarta}

Awal kelahiran keris Tangguh Ngéntha-éntha Yogyakarta menurut sumber data yang didapat, baik dari lapangan maupun dari para ahli, diduga kuat terkait dengan kehadiran empu Éntha Wayang di desa yang sekarang dikenal sebagai desa Ngéntha-éntha itu. Menurut Supardi Prawirodipuro seperti yang dikutip S. Lumintu menyebutkan, bahwa empu pertama yang menetap di desa tersebut adalah Empu Wayang (Éntha Wayang) (Lumintu, 2004: 17). Jejak Empu Wayang di Desa Ngéntha-éntha kemungkinan berkaitan dengan peristiwa pecahnya kerajaan Mataram Kartasura. Dalam tulisan R.M. Soedarsono, Kerajaan Mataram pada perjanjian Giyanti tahun 1755, dipecah menjadi Kasunanan Surakarta dan Kasultanan Yogyakarta (1997: 22). Empu Wayang sudah dikenal sebagai seorang empu ahli keris yang mengabdikan diri di kerajaan Mataram Kartasura (Darmosoegito, 1961: 47). Seiring bergesernya kekuasaan kerajaan Mataram Kartasura, sebagian para abdi empu termasuk Empu Wayang bergerak ke Yogyakarta.

Gejolak kerajaan biasanya sangat berpengaruh terhadap seluruh kehidupan masyarakat, termasuk para ahli pembuat keris atau empu yang mempunyai pekerjaan yang dianggap sulit, sehingga jenis pekerjaan itu nilainya begitu berharga pada zamannya (Raffles dalam Prasetyaningrum, 2008: 109). Mereka, empu keris biasanya dijadikan keluarga atau punggawa yang hidupnya dekat dengan kekuasaan, namun mana kala kekuasaan raja sedang goyah, aktivitas mereka juga tidak dapat berjalan semestinya. Jika kemudian kondisi kekuasaan tidak mampu lagi mencukupi kehidupan mereka, maka banyak empu yang menyingkir (Ranuwijaya, 2009: 39). Kegoncangan kerajaan menurut Joko Sukiman, biasanya mendorong banyak empu keris 'ampuh' pindah tempat, apalagi kalau kurang mendapatkan penghargaan dari sang raja (1983: 2). Di sisi lain, empu keris yang hakikatnya adalah pembuat karya seni, menurut Isaac Groneman, keris tidak dihargai sebagai karya seni, para empu hidupnya sama miskinnya dengan para tetangga lainnya, meskipun mereka abdi utama kerajaan yang harus merawat seluruh senjata pusaka (1910: 93).Terkait dengan kondisi krusial yang sering terjadi di kerajaan, menurut Hamzuri, menyebabkan pusat-pusat pembuatan keris di Jawa sering berpindah-pindah tempat, sesuai dengan penghargaan atau jatuh bangunnya kerajaan (1984: 1).

Kisah Empu Wayang memasuki Desa Ngéntha-éntha menurut Empu Sungkowo, bersamaan dengan berdirinya kerajaan Yogyakarta Hadiningrat. Empu Wayang bersama kawan-kawan empu yang lain, para pengikut Pangeran Mangkubumi berpindah tempat dari Kartasura ke Yogyakarta. Mereka kemudian menempati desa-desa di sekitar Godean. Desa-desa itu letaknya terpencar, 
sekarang dikenal sebagai Desa Ngéntha-éntha, Balangan, Cebongan, Sumberan, Jenggalan, dan seterusnya. Empu Wayang sendiri merintis desa dan membuka lahan yang dijadikan desa baru guna membangun tempat tinggal dan besalènnya. Di desa baru (belum ada nama Ngéntha-éntha) itulah Empu Wayang mulai meneruskan kariernya sebagai ahli tempa logam, pembuat segala persenjataan, dan lain-lain terutama keris pusaka (Empu Sungkowo, 2011).

\section{Kehidupan Berkarya Empu Wayang}

Kehidupan berkarya empu Wayang di desanya, dalam waktu yang terus berjalan mempunyai kesempatan untuk menularkan dan memelihara seperangkat corak bentuk keris di desanya. Meskipun menurut Bambang Harsrinuksmo, tanda-tanda keris buatan empu Wayang tidak tercatat, namun menurut beberapa kalangan pecinta keris dari Yogyakarta, keluarga Empu Wayang selalu membuat keris dengan gaya penampilan ramping. Bentuknya tampak manis dan bilahnya lebih tipis dibanding bilah keris buatan Kartasura (2008: 157). Tiruan-tiruan keris Empu Wayang terus berlangsung, yang kemudian justru mampu menjadi citra tradisi kolektif keempuan keris masyarakat desanya. Semakin lama citra itu memunculkan gaya atau yang disebut dengan nama Tangguh Ngéntha-éntha Yogyakarta sebagai milik masyarakat. Ungkapan kreativitas masyarakat seperti itu menurut Kayam pada mulanya berasal dari manusia-manusia pencipta anggota masyarakat (Kayam, 1981: 39).

Keempuan Wayang sendiri bersumber dari keturunan Tumenggung Supadriya, seorang empu keris terkenal dari kerajaan Majapahit. Garis kesinambungan itu berturutturut tidak hanya sampai pada empu Wayang, namun juga sampai pada Empu Sungkowo.
Urutan kesinambungan silsilah keturunan itu, selain tertulis dalam selembar kertas yang berbingkai kayu, terpajang pada dinding rumah Empu Sungkowo yang juga tertera pada buku tulisan Ki Darmosoegito sebagai berikut.

Tumenggung Supadriya,
empu di zaman Majapahit,
menurunkan Empu Jaka Supa, alias
Pangeran Sedayu, menurunkan
Supanom di Tuban; menurunkan
Empu Sektilanang di Tuban;
menurunkan Nyai Pajang Emas, istri
Pangeran Pajang Emas, di Mataram;
menurunkan Empu Tjindeamoh di
Mataram; menurunkan Empu
Supanjang di Mataram; menurunkan
Empu Éntha Wayang di Kartasura;
menurunkan Mas Ayu Kadarsih, istri
Pangeran Hangabei, di Kartasura;
menurunkan Raden Ayu Pandhit, istri
Empu Pandhit, di Surakarta;
menurunkan Nyai Badur, istri Empu
Badur, di Ngéntha-éntha, Yogyakarta;
menurunkan Empu Kartajuda di
Ngéntha-Entha, Yogyakarta;
menurunkan Empu Djoirana di
Lumajang; menurunkan Empu
Supainangun, di Ngéntha-Entha,
Yogyakarta (Darmosoegito, 1961: 47-
48).

Perlu ditambahkan di sini, bahwa Empu Supoinangun menurunkan Yosopangarso, Genyodiharjo, Wiknyosukoyo, dan Jeno Harumbrojo. Wiknyosukoyo menurunkan Sungkowo yang sejak kecilnya dipungut menjadi anak angkat Harumbojo, pamannya sendiri. Mereka, anak-anak Supoinangun dan Sungkowo cucunya, adalah generasi penerus tradisi keris Tangguh Ngéntha-éntha Yogyakarta yang taat pada profesinya, Empu 
Sungkowo masih sampai sekarang (Sungkowo, 2010).

Kisah Empu Wayang, menurut Ponimin Ciptoharjono (77 tahun), Mujihadi (71 tahun), dan FX. Samijo (80 tahun), meskipun mereka tidak menyaksikan secara langsung kehidupan Empu Wayang, namun mereka masih ingat dan mempercayai cerita orang tuanya sendiri tentang asal mula desanya. Keberadaan Desa Ngéntha-Entha, dikarenakan adanya Empu Wayang yang mengembangkan ke-pandé-an mengolah besi untuk dibuat keris. Ke-pandé-an Empu Wayang itu kemudian mengalir kepada anak turunnya, juga mengalir kepada warga masyarakat sekitarnya sampai turun-temurun. Oleh karena itu, warga di sini selain ada yang mampu menjadi Empu keris, mereka juga ada yang mampu menghasilkan alat-alat pertanian, seperti sabit, cangkul, dan sebagainya. Seluruh ke-pandé-an tempa logam penduduk Desa Ngéntha-Entha sampai saat ini, tidak lain berawal dari Empu Wayang (Ponimin Ciptoharjono, Mujihadi, dan FX. Samijo, 2012).

Sosok Empu Wayang digambarkan oleh masyarakat desa Ngéntha-Entha sebagai seorang yang mempunyai kemampuan "lebih". la sebagaimana para empu keris pada zaman dahulu menurut Ki Darmosoegito, dianggap sebagai orang "suci" yang mempunyai daya pengaruh terhadap lingkungan sekitarnya (Darmosoegito, 1961: 17). Jejak kemampuan Empu Wayang selain masih dirasakan oleh warga desa tempat tinggalnya, juga bagi para penggemar dan para ahli keris. Desa itu menjadi dikenal dan mempunyai cerita yang membanggakan bagi banyak kepentingan. Faktor keturunan Empu Wayang yang berdarah Tumenggung Supodriyo, seorang empu keris terkenal dari kerajaan Majapahit (Danumurti, 2010: 13), semakin memantapkan sejarah keberadaan
Empu Wayang sebagai perintis profesi masyarakat desanya. Jejaknya yang kuat dibuktikan oleh nama depan pribadinya yang terpatri dengan Desa Ngéntha-éntha. Meskipun kapan dan bagaimana awal penyebutan nama depan Wayang, yaitu Éntha menjadi Ngéntha-éntha, baik sebagai nama desa maupun sebagai nama Tangguh keris, sampai saat ini belum ada yang mengetahui secara pasti. Meskipun demikian masyarakat pada umumnya mewarisi warisan nama tanpa mempermasalahkan kapan lahirnya nama tersebut. Asal-usul nama desanya dari kata Éntha menjadi Ngéntha-éntha sudah sejak dahulu dipercayai, dan diganggap bukan cerita mitos belaka, tetapi fakta yang pernah terjadi pada zamannya.

Empu Wayang telah menjadi milik bersama masyarakat atau menurut Hildred Geertz (1981: 27), disebut karakter korporatif. Suatu bentuk kepemilikan bersama yang sangat besar di desa-desa, seperti pekuburan, tempat dimakamkannya pendatang asli pertama yang dahulunya telah membersihkan hutan-hutan rimba dan menggarapnya menjadi sawah-sawah. Para penduduk setempat secara batiniah dianggap sebagai keturunan dari penghuni pertama desa tersebut. Empu Wayang pun dianggap telah berjasa sebagai cikal bakal desa, sekaligus perintis profesi yang menghidupkan kehidupan masyarakat Desa Ngéntha-éntha. Jasa-jasa Empu Wayang bagaimanapun tidak akan mudah dilupakan, apalagi diyakini sebagai nenek moyang mereka yang pantas diingat dan dihargai tidak hanya oleh pewarisnya sendiri, tetapi juga oleh penduduk desa dan masyarakat budaya keris yang terkait. 


\section{Generasi Penerus Keempuan Wayang}

Setelah meninggal Empu Wayang dimakamkan di makam Gedong, yaitu makam Desa Ngéntha-éntha yang letaknya di sisi timur desa tersebut. Batu nisannya masih terawat baik sampai sekarang. Surutnya Empu Wayang, maka keempuan keris Desa Ngénthaéntha dijalankan terutama oleh pewaris anak turunannya sendiri, yaitu Empu Badur. Setelah Empu Badur selanjutnya oleh Empu Kartayuda. Sebagai keturunan Empu Wayang, kedua empu keris tersebut bekerja mengikuti cara yang dilakukan Empu Wayang, namun sayangnya tidak banyak yang dapat mengungkapkan secara lebih mendalam kisah hidup kedua empu tersebut. Menurut para pengamat, hal itu dikarenakan kedua empu tersebut tidak membuat corak baru, mereka setia meneruskan identitas Empu Wayang yang telah menjadi kerangka ciri khas desanya. Setelah meninggal kedua empu tersebut juga dimakamkan di tempat yang sama, yakni di makam Gedong, Ngénthaéntha. Selanjutnya tradisi keempuan dilanjutkan oleh Empu Djoirono, keturunan Empu Kartayuda. Empu Djoirono kemudian menurunkan Empu Supoinangun yang sangat dikenal masyarakat sampai akhir hayatnya di Ngéntha-éntha.

\section{Kempuan Supoinangun}

Sejak zaman Sultan Hamengku Buwana VIII bertahta di Keraton Yogyakarta, Empu Supoinangun sangat dikenal, karena teknik tempanya sangat hebat. Menurut Ki Darmosoegito (1963: 22), kehebatannya membuat RM. Surachman dan RM. Prawiranegara tertarik mengarahkan Empu Supoinangun membuat pusaka keris yang dibutuhkan orang-orang asing, seperti keris dengan pamor nekel, srasrahan salaka, suwasa, dan ada yang ditabur intan kecil-kecil sebagai hasil karyanya. Keris karya Empu Supoinangun pernah tampil dalam pameran di Yogyakarta dan ternyata membuat takjub orang asing yang melihat keris berpamor tersebut.

Berdasar pengakuan Ciptoharjono, dahulu ketika kecil pernah menyaksikan langsung Empu Supoinangun saat bekerja membuat keris. la suka menunggui Empu Supoinangun di besalèn-nya, sehingga ia tahu bagaimana sang empu membuat keris. "Biyen mbah-mbahku kuwi yo gawe keris wiwit jaman kuna, aku mung nirokke" 'dahulu nenek-neneku juga membuat keris mulai zaman dahulu, saya hanya menirukan', begitu cerita Supoinangun kepada Ciptoharjono kecil. Ciptoharjono juga menunjukkan besalèn Empu Supoinangun yang aslinya ada di desa Ngéntha-éntha, namun setelah usianya lanjut, kemudian pindah ke utara, yaitu di Desa Jenggalan, atau sekarang menjadi wilayah RT.01 Desa Ngéntha-éntha. Diceritakan bahwa dahulu ada banyak pembuat keris di desa tersebut, tidak hanya Empu Supoinangun, namun lama-kelamaan berkurang dan bahkan habis, kecuali Supoinangun. Penyebabnya utama adalah karena harus prihatin untuk 'mengisi' keris, dan tidak semua orang mampu melaksanakannya. Oleh karena itu, para empu kemudian lebih memilih membuat cangkul dan sabit yang dirasa lebih mudah dan menguntungkan, kecuali Empu Supoinangun (2011). Menurut Gendut (60 tahun), warga desa Ngéntha-éntha, desa itu tidak dapat dipisahkan dengan kepandaian Empu Supoinangun. Dahulu, semua warga mampu membuat aneka ragam alat-alat dari hasil tempa besi, selain ada yang ahli membuat alat pertanian, juga ada yang mampu membuat senapan, pedang, dan keris. Terkait dengan itu, dahulu orang-orang di desa ini banyak yang memakai nama depan Supo, karena 
nama Supo dianggap identik dengan seseorang yang ahli dalam ke-pandé-an logam (2011).

Di setiap rumah penduduk terdapat bangunan rumah besalèn yang biasanya terletak di sekitar rumah tinggalnya. Meskipun demikian ke-pandé-an membuat alat-alat, seperti cangkul dan sabit yang bersifat turuntemurun, sekarang sudah ditinggalkan dan nyaris punah. Berbeda dengan kepandaian Empu Supoinangun yang profesinya membuat persenjataan khususnya keris pusaka, meskipun mengalami pasang surut, namun sampai sekarang masih diteruskan oleh anak turunnya, bahkan sekarang sudah mendapat sambutan lagi dari banyak pihak.

Empu Supoinangun adalah seorang empu yang hidup pada zaman pemerintahan Sri Sultan Hamengku Buwana VII, VIII, dan IX. la lama tinggal dan berkarya di Desa Ngénthaéntha, karena itu keris-keris buatannya semakin memantapkan sebagai Tangguh Ngéntha-éntha Yogyakarta. Empu Supoinangun merupakan salah seorang empu terakhir menjelang Indonesia merdeka. Ayah Empu Supoinangun, Empu Joyotaruno yang lebih dikenal Empu Djoirono adalah empu yang mengabdi pada Sri Sultan Hamengku Buwana VII. Walaupun Empu Supoinangun tidak sempat menurunkan ilmunya kepada anak-anaknya, tetapi Yosopangarso, Genyodiharjo, Wiknyosukoyo, dan Harumbrojo dapat meneruskan pekerjaan keempuan ayahnya (Harsrinuksmo, 2008: 452).

Setelah meninggal tahun 1963 yang lampau, Empu Supoinangun dimakamkan di makam Timoho, Desa Gatak Sumberagung, Moyudan, Sleman. Pusaranya yang terletak di desa tersebut masih terawat dan sering dikunjungi oleh peziarah, baik dari masyarakat sekitar maupun dari luar daerah. Makammakam para empu keris desa Ngéntha-éntha seperti makam-makam tokoh-tokoh di Jawa, dijadikan tempat berziarah (Hadikusumo, 2002: 5).

\section{Memasuki Tahap Inspirasi Bangkit}

Putra-putra keturunan Empu Supoinangun, sekaligus murid, belum ada yang berkeinginan meneruskan keempuan ayahnya. Faktor penyebabnya sangat kompleks, selain karena pergeseran zaman, pergeseran kepercayaan, dan lain-lain. Menurut Empu Sungkowo, hal yang paling berat adalah ketiadaan dana untuk operasional. Saat itu, selain sangat sulit mendapat modal, juga langka bahan pamor, sehingga tak berdaya lagi untuk memulai pekerjaan membuat keris. Lama-kelamaan terjadilah keruntuhan serius, bahkan profesi keempuan tak terusik oleh siapapun. Akan tetapi mulai tahun 1970 sampai menjelang tahun 1973, Harumbrojo, anak bungsu Empu Supoinangun, mulai bangkit hatinya melalui caranya yang unik. $\mathrm{Di}$ suatu malam Harumbrojo sedang tidur, bermimpi, diminta membantu ayahnya membabar/membuat keris. Setelah terbangun, ia ingat mimpinya malam itu, tetapi dianggapnya hanya sebagai bunga-bunga tidur saja, sehingga tidak dihiraukannya. Sekitar tiga bulan kemudian, Harumbrojo bermimpi seperti mimpinya terdahulu, yaitu ditemui mendiang ayahnya. Empu Supoinangun, ayahnya, meminta dirinya untuk membuat keris. Mimpi kedua tersebut juga dilewatkan begitu saja, belum menggerakan hati Harumbrojo. Akan tetapi, sekitar tiga bulan kemudian, Harumbrojo dalam tidurnya bermimpi lagi, dalam mimpinya muncul gambaran sang ayah meminta dirinya untuk meneruskan pekerjaan membuat keris. Mimpi yang ketiga kalinya ini, karena isi pesan sama dengan mimpi yang pertama maupun kedua, maka terusiklah hati 
Harumbrojo. Kata hatinya menganggap itu sebagai petunjuk Tuhan yang diberikan kepadanya sebagai wangsit atau amanat yang harus dilaksanakan.

Harumbrojo sebagai orang Jawa merasa mendapat amanat. Meskipun kekurangan modal, keterampilan terbatas, serta minimnya bahan pamor, tidak mengendorkan tekatnya seperti yang dipesankan dalam mimpi. Sangat ingin segera mewujudkan mimpinya, Harumbrojo menawarkan ajakan kapada kakak sulungnya yang bernama Yosopangarso. Tawaran itu diharapkan kelak tidak akan mengalami kesulitan dalam proses menggali pengetahuan keempuan yang ditinggalkan ayahnya. Meskipun awalnya Yosopangarso tidak mau menerima tawaran itu, namun karena dibujuk terus-menerus oleh Harumbojo dengan landasan kesetiaan terhadap orang tuanya, ajakan tersebut akhirnya diterima. Terjadilah duet adik kakak dengan mulai membangun besalèn di desa Gatak, namun tempat itu sekarang sudah ditinggalkan, dan sisa peralatannya masih tersimpan di almari.

\section{Bekerjasama dengan Peneliti dan Pemerhati Keris}

Pada tahun 1973, seorang peneliti budaya keris Jawa asal Hawaii, bernama Garret Solyom mengunjungi Desa Ngénthaéntha Yogyakarta. Kedatangan Solyom, selain terkait dengan penelitiannya tetang budaya keris Jawa, juga kemudian memberikan dorongan dan uluran tangan kepada Yosopangarso dan Harumbrojo.

We would like to acknowledge and thank the Ford Foundation Indonesia Traditional Arts Committee for their timely support of the two keris smiths, Yosopangarso and Jeno [Harumbrojo]. We hope their example will provide stimulus needed to bring greater local support to all tradition arts, not only to keris smithing (Solyom, 1978: 3).

Almarhum Panembahan Harjonagoro alias Go Tik Swan berperan mengarahkan dan mendanai proyek Harumbojo. Ketiga orang dan sesepuh perkerisan Haryono Haryo Guritno, membuat Empu Yosopangarso dan adik-adiknya melewati masa-masa sulit.

Seiring dengan berjalannya waktu, seorang kapten kapal berkebangsaan Jerman bernama Dietrich Drescher, menaruh perhatian kepada budaya keris Jawa. Pada tahun 1975, ia juga mengunjungi Desa Ngéntha-éntha meminta kepada Yosopangarso bersaudara untuk membuatkan keris. Drescher mengerti bahwa Yosopangarso bersaudara saat itu masih sedikit enggan melakukan percobaan membuat keris, namun ia terus memberi semangat dan dorongan agar tidak menyerah begitu saja. Berbagai pertimbangan dan desakan yang terus-menerus, akhirnya membuat Yosopangarso dan adik-adiknya: Genyodiharjo, Wiknyosukoyo, dan Jeno Harumbrojo melaksanakan percobaan membuat keris. Mereka kembali bekerja bersama-sama merekonstruksi metode dan proses keris, satu per satu keris hasil percobaannya lahir (Guritno, 2006: 50). Kelahiran itu mengartikan bahwa keris Tangguh Ngéntha-éntha Yogyakarta telah mendapat energi positif bagi eksistensi sejarahnya. Drescher juga menyediakan bahan pamor yang sulit didapat di dalam negeri. Meninggalnya sparing partner, Yosopangarso tahun 1990, memang memukul Harumbojo dan keluarganya. Akan tetapi tidak lantas yang ditinggal mandul berkarya, justru mencambuk konsistensi Harumbojo sebagai empu yang 
masih nguri-uri tradisi perkerisan dengan pakem keempuan klasik (Anshori, 2009: 16).

Para empu keris Tangguh Ngénthaéntha Yogyakarta berkat dorongan Drescher berhasil merekonstruksi metode kuno, yaitu berdasar patokan-patokan tradisi. Orientasi garapannya lebih menuju ke arah tercapainya mutu nilai budaya, bukan yang lain. Menurut Koentjaraningrat, sasaran penilaian karya yang berorientasi nilai budaya hasilnya bukan berupa harta, tetapi karya demi karya itu sendiri (1981: 35). Terkait dengan konteks empu keris Tangguh Ngéntha-éntha Yogyakarta, mereka membuat keris baru lebih mengutamakan mutu nilai budaya, dari pada nilai ekonominya. Selain masih melakukan ritus tradisi secara ketat, juga prosesnya pantang menggunakan alat-alat canggih. Serumit apa pun proses pembuatan bilah keris tetap dijalankan dengan alat-alat sederhana, seperti proses keris zaman dahulu.

\section{Penutup}

Suatu perjalanan yang memakan waktu sangat panjang, karena hingga kini terbukti aktivitas tersebut masih kembali berjalan sampai generasi empu keris yang hidup di masa reformasi. Menurut Sungkowo, pembuatan keris masih tradisional, termasuk alat-alatnya, serta masih memperhitungkan hari-hari pantangan. Jika diterjang, kadangkadang membakar saja tidak dapat merah, semua proses masih di atas tanah. Ini menunjukan bahwa tradisi keris masih utuh, hanya bagi mereka yang bisa menjalankan persyaratan tersebut mampu menjadi seorang empu keris. Tokoh-tokoh terpilih, seperti Empu Wayang, Supoinangun, Yosopangarso, Harumbrojo, dan Sungkowo mampu menjadi empu keris yang handal. Kekhasan penampilan tradisinya justru ditempatkan untuk memasuki masa kini. Berkat keberanian mengambil risiko memasuki tantangan zaman teknologi modern, pembuatan keris hidup lagi dan dapat disaksikan sampai sekarang. Kekuatan, semangat, bakat, kesetiaan, dan konsistensi yang menjiwai tekadnya juga telah memicu pusat-pusat keris yang lain di Indonesia untuk ikut berkembang.

Mereka kemudian mampu mengisi peluang hidup, mewarnai kembali keragaman budaya tradisi di antara budaya Jawa yang masih eksis atau bertahan hidup bersama budaya modern saat ini. Di samping kemudian mengundang apresiasi banyak pihak, seperti mendapatkan penghargaan dari Presiden Megawati Sukarno Putri, yang juga mengantarkan keris Indonesia diakui sebagai warisan dunia, diakui oleh UNESCO tahun 2005. Lembaga kebudayaan dunia tersebut memandang keris sebagai warisan masa lampau, yang dinikmati saat ini, dan akan diteruskan kepada generasi yang akan dating (Almatera, 2010: iv).

\section{Daftar Pustaka}

Almatera, Tim. 2010. Warisan Budaya Dunia: Karya Agung Sejarah Manusia yang Memiliki Nilai Universal Luar Biasa \& Paling Berpengaruh di Dunia. Yogyakarta: Almatera Publising.

Anshori, Munif Al. 2009. Pustaka Keris: Khasanah Budaya Nusantara. Vol 17. Jakarta: PT. Pustaka Keris Indonesia.

Capra, Fritjof. 1997. Titik Balik Peradaban: Sain, Masyarakat dan Kebangkitan kebudayaan Terj. M Thoyibi. Yogyakarta: Yayasan Bentang Budaya.

Danumurti, RS. 2010. “Membabar Keris Empu Jeno" dalam Keris Khasanah Budaya 
Nusantara. Vol 17. Jakarta: PT. Pustaka Keris Indonesia.

Durignand, Jean. 2009. Sosiologi Seni. Terj. Yupi Sundari dkk. Bandung: Sunan Ambu STSI Press Bandung.

Garret dan Bronwen Solyom. 1978. The World of the Javanese Keris. Honolulu, Hawaii: East-West Center.

Geertz, Hildred. 1981. Aneka Budaya dan Komunitas di Indonesia. Terj. A. Rachman Zainuddin. Jakarta: Yayasan Ilmu-ilmu Sosial FIS-UI.

Groneman, Isaac. 1910. Der Kris Der Javaner. Internationales Archiv Fur Ethnographie, Band XIX.

Guritno, Haryono Haryo. 2006. Keris Jawa: Antara Mistik dan Nalar. Jakarta: PT. Indonesia Kebanggaanku.

Hamzuri. 1984. Keris. Jakarta: Jambatan.

Harsrinuksmo, Bambang. 2008. Ensiklopedi Keris. Jakarta: PT. Gramedia Pustaka Utama.

Kayam, Umar. 1981. Seni, Tradisi, Masyarakat. Jakarta: Sinar Harapan.

Kedaulatan Rakyat, 11-5-1997.

Koentjaraningrat. 1981. Kebudayaan Mentalitas dan Pembangunan. Jakarta: Gramedia.

Lumintu, S. 2004. IImu Keris. Yogyakarta: Naskah untuk Kalangan Sendiri.
Raffles, Thomas Stamford. 2008. The History of Java. Terj. Eko Prasetyaningrum dkk. Yogyakarta: Narasi.

Ranuwijaya, RDS. 2009. "Dhapur Putut Kembar" dalam Pusaka Keris Vol. 16. Jakarta: PT. Pustaka Keris Indonesia.

Ricklefs, M.C. 2002. Yogyakarta di Bawah Sultan Mangkubumi 1749-1792: Sejarah Pembagian Jawa. Terj. Hartono Hadikusumo. Yogyakarta: Matabangsa.

Saefuddin, Achmad Fedyani. 2006. Antropologi Kontemporer: Suatu Pengantar Kritis Mengenai Paradikma. Jakarta: Prenada Media Group.

Sejarah Daerah Istimewa Yogyakarta. 1976/1977. Depdikbud Pusat penelitian Sejarah dan Budaya, Proyek Penelitian dan Pencatatan Kebudayaan daerah.

Soedarsono, R.M. 1997. Wayang Wong: Drama Tari Ritual Kenegaraan di Keraton Yogyakarta. Yogyakarta: Gadjah Mada University Press.

Soekiman, Djoko. 1983. Keris: Sejarah dan Fungsinya. Yogyakarta: Javanologi.

Wawancara dengan Ponimin Ciptoharjono tanggal $12-10-2011$. dengan Gendut tanggal $15-11-$ 2011.

tanggal 28-12-20011. 